Military Technical College

Kobry El-Kobbah, Cairo, Egypt.

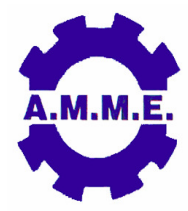

$15^{\text {th }}$ International Conference on Applied Mechanics and Mechanical Engineering.

\title{
SIMPLIFIED TECHNIQUE FOR RECYCLING OF MICRO AND NANO-COMPOSITE WITH INDUSTRIAL WASTES
}

\author{
H. Ahmed ${ }^{*}$
}

\begin{abstract}
In this work, the interest in composite materials to increase their participation in future lightweight structures for building applications in the next generation is presented. Simplified methods for the recycling of composite materials and other industrial wastes were developed. The process should be automatic in all cases. First step is preparation of wastes from different industrial sources by grinding and mixing .Second step is manufacturing of certain iron molds with good inner surface finish, the molds were lubricated by specials oils. The rest step is the design of machine for remanufacturing of disposable material at certain conditions depends on the percentage of additives. All elements are exposed directly to be pressing and shaped by the usual procedures. Finally, each type of material takes different recycling procedures.
\end{abstract}

\section{KEY WORDS}

Nano-composites, Recycling, Waste recovery, Manufacturing industries, Industrial waste.

* Dr. Eng., Consultant in materials sciences \& materials applications, Egypt. Email: Hebatalrahman11@yahoo.com, Hebatalrahman@Naseej.com. 


\section{INTRODUCTION}

Replacement of traditional metal components by composite plastics in applications such as bumpers, under bonnet components, body panels and exterior trim has significantly reduced the weight of the average car. Typically, $10 \%$ of a vehicle's weight (wt\%) is made up of plastics and plastic composites, and for some lightweight vehicles this may be up to $20 \mathrm{wt} \%$. Composites are increasingly used since they have the advantages of strength, durability and corrosion resistance together with low weight. Composites are composed of many different components, including glass fibre reinforcement, filler material and the thermoset or thermoplastic polymer, which is the matrix or continuous phase. The plastic polymer components commonly used include thermoset polyester, phenolic resin, epoxy resin, polypropylene and vinyl ester resin. It is the mixture of components embedded in the matrix that make composites difficult to recycle and the reason why such a high percentage is sent to landfill [1].

Figure 1 shows the percentages of composite wastes in residual wastes as recorded in year 2003. Consequently, there is a need to identify novel process routes to enable the recycling of composite materials [2-4].

Plastics form a fast increase percentage of the total solid wastes because their use is very important now in the modern life. Plastics basically consist of carbon, hydrogen and oxygen but they are not biodegradable [5-6].

Many varieties of plastics find their way into waste disposal streams but three types polyolefin, polystyrene, and poly vinyl chloride (PVC)-make up more than four-fifths of the total. One possible method of recycling plastics is to use it in the form in which it was first manufactured; i.e. by mixing the raw plastic during the production of new packs. However, there are problems due to a large number of Different grades of material within each major plastic type, and the grade employed depends on the characteristics required in the particular pack [7-8].

Composition of residual waste 2003

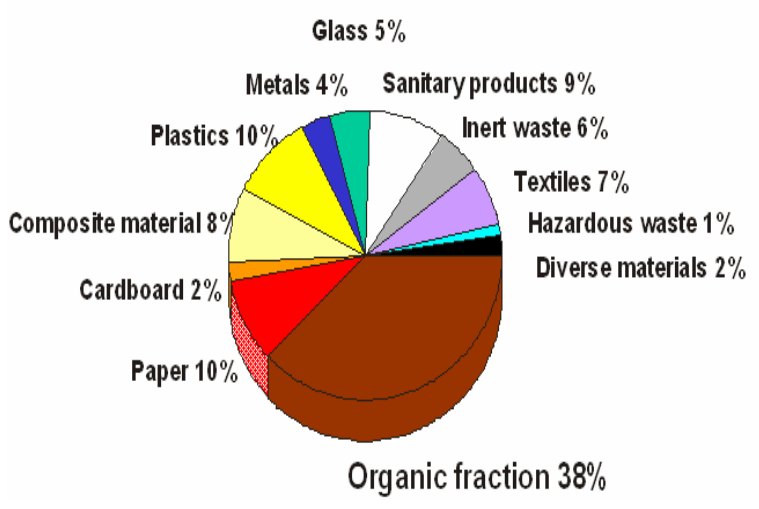

Fig. 1. The percentages of composite wastes in residual wastes 2003 [4]. 
Since mixed plastics cannot be recycled in the above manner, and this is the most common form of plastics in the municipal solid waste, plastics may be treated to produce hard and soft waxes, greases, adhesives, and tars as well as a range of gases. Plastics may be irradiated by ultra violet to contain small pieces then mixed with the soil and can be decomposed by normal soil bacteria into basic chemicals, recycling may be accomplished by reusing the plastic in another form so our new composite material solve most of the problems of recycling plastics $[9,10]$.

Separation of the glass fibre from the filler was achieved using a drum carder machine, which gently separates the fibres from the friable char and filler matrix [11]. The fibres can then be used as char-coated fibres to produce new composite plastic materials. Alternatively, the blackened glass fibre can be cleaned using low-temperature furnace oxidation to burn off the char to produce cleaned fibre. The recovered glass fibres, both cleaned and char-coated, were made up into test samples of a new composite by the industrial partners [12-14]. Test samples incorporating $25 \mathrm{wt} \%$ of the recovered glass fibre and $75 \mathrm{wt} \%$ virgin glass fibre were compared to a controlled sample containing $100 \mathrm{wt} \%$ virgin glass fibre $[15,16]$. The results showed that up to $25 \mathrm{wt} \%$ of recycled fibre could successfully be incorporated into a new composite while still meeting manufacturer's specifications $[17,18]$.

Slag is the most important waste in metals industries. The process of iron melting involves the formation of slag. The main sources of slag in a furnace are the refractory lining, coke ash and various oxides brought in during charging fluxes, scale and sand are formed in the furnace such as $\left(\mathrm{FeO}, \mathrm{SiO}_{2}, \mathrm{MnO}\right.$, etc.). Slag control for minimizing the melting temperature and viscosity of the slag is carried out by adding limestone $[19,20]$. The basicity of the acidic slag is $\mathrm{CaO} / \mathrm{SiO}_{2}=0.5-0.6$. When higher amount of limestone added to the charge, the slag are basic $\mathrm{CaO} / \mathrm{SiO}_{2}=1.5-2$, When desulphurization reaction take place $\mathrm{CaS}$ and $20-30 \% \mathrm{FeO}$ are found in the slag [21]. Figure 2 shows useful ores and wastes during metals manufacturing.

\section{EXPERIMENTAL WORK}

\section{Machine}

New method for the recycling of composites reinforced by different types of additives and fibers, which is non-recyclable by traditional methods, is introduced. Temperature controller is installed to maintain the temperature of the mixture constant. The compound formed maintain in the elastic form. It shredded to the appropriate sizes. Material is cooled after deformation by air stream. The resulting material is combined with thermoplastics or metals materials and manufactured under certain conditions of temperature and pressure appropriate to the type of matrix. Figure 3 shows the manufacturing utensils for waste recycling, the new technique has advantages such as simple design, good surface finish of the final product, low cost and the products resulting from the system have good surface finish. 


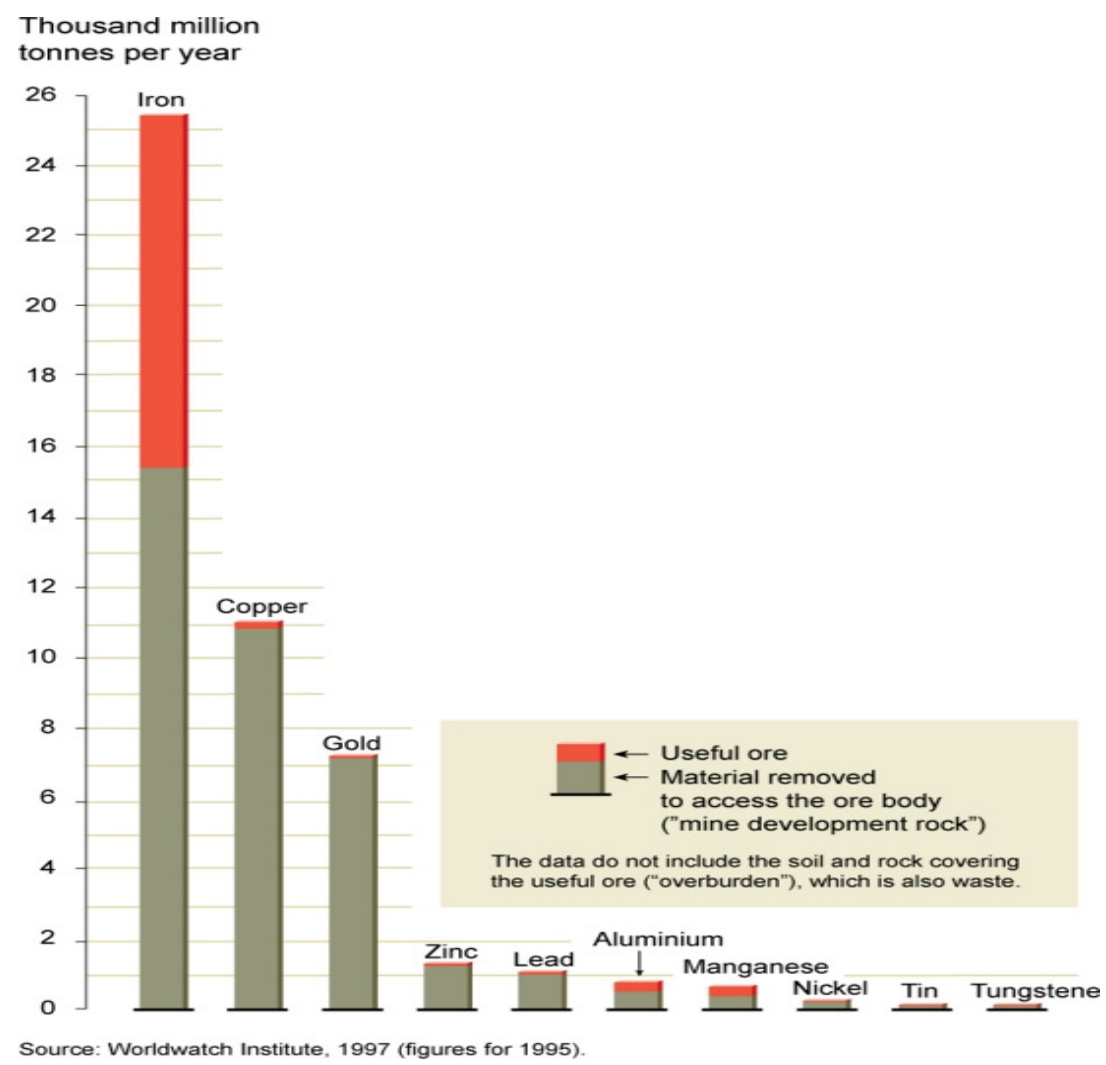

Fig. 2. Useful ores and wastes during metals manufacturing [21].

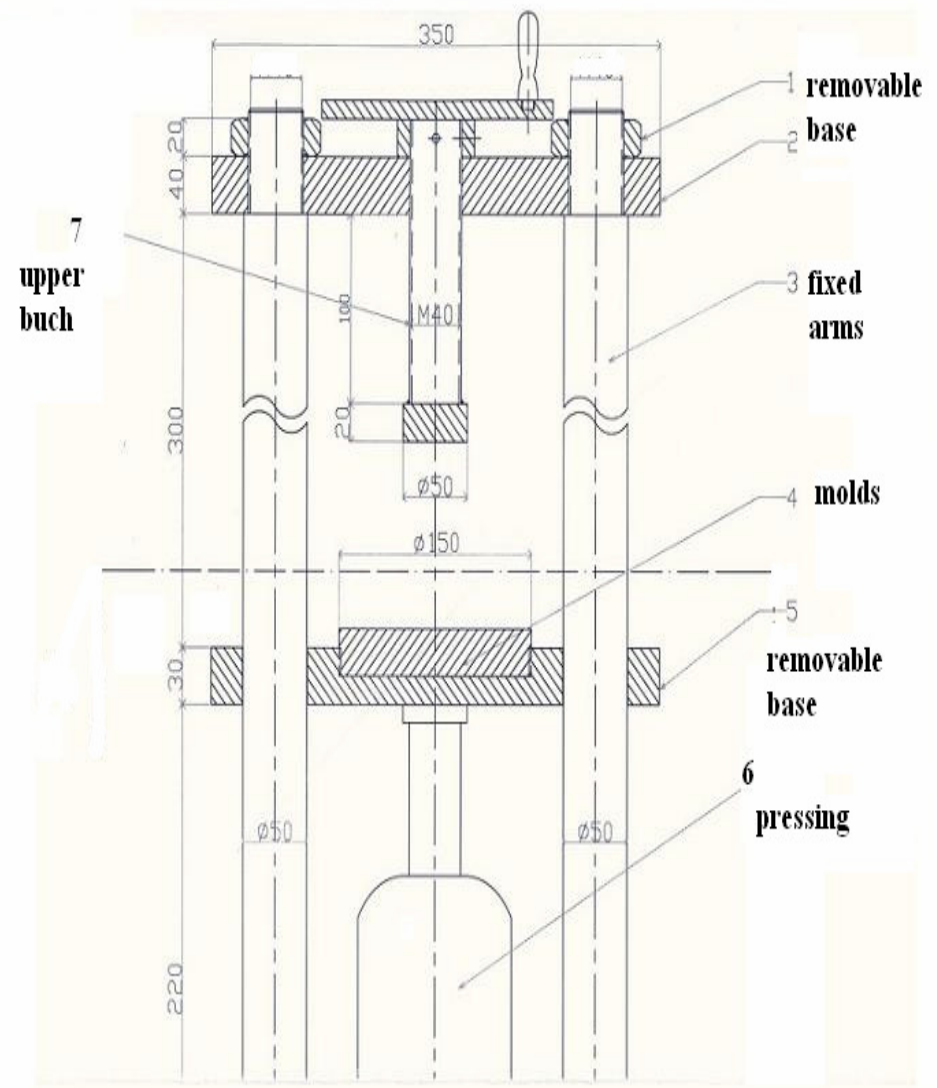

Fig. 3. The manufacturing utensils for waste recycling of composites. 


\section{Preparation of Materials}

\section{Grinding}

A blinder with variable speeds is used to change the pieces of thermo-plastics into powder form, The blinder speed is about $15,500 \mathrm{rpm}$, work at 200 volt - $50 \mathrm{hz}$, and the grinding time is about $90 \mathrm{sec}$. Switch off for cooling is lasted about $180 \mathrm{sec}$ to prevent the agglomeration of the particles and achieve reasonable degree of quality in grinding. Powder size is less than or equal to $1 \mathrm{~mm}$.

\section{Mixing}

Mechanical mixing for thermoplastic with additives and wastes are done in the powder form (less than $1 \mathrm{~mm}$ diameter), slag, master patch, other modifier and a short fiber were added with different ratio the amount of materials are calculated by changing the volume fraction percent into weight percent.

\section{Mold preparation}

1. The mold is made from Iron in cylindrical shape as shown in Fig. 4, the inner surface of the mold is smooth and lubricated with certain types of oils.

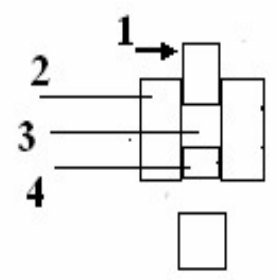

(1)

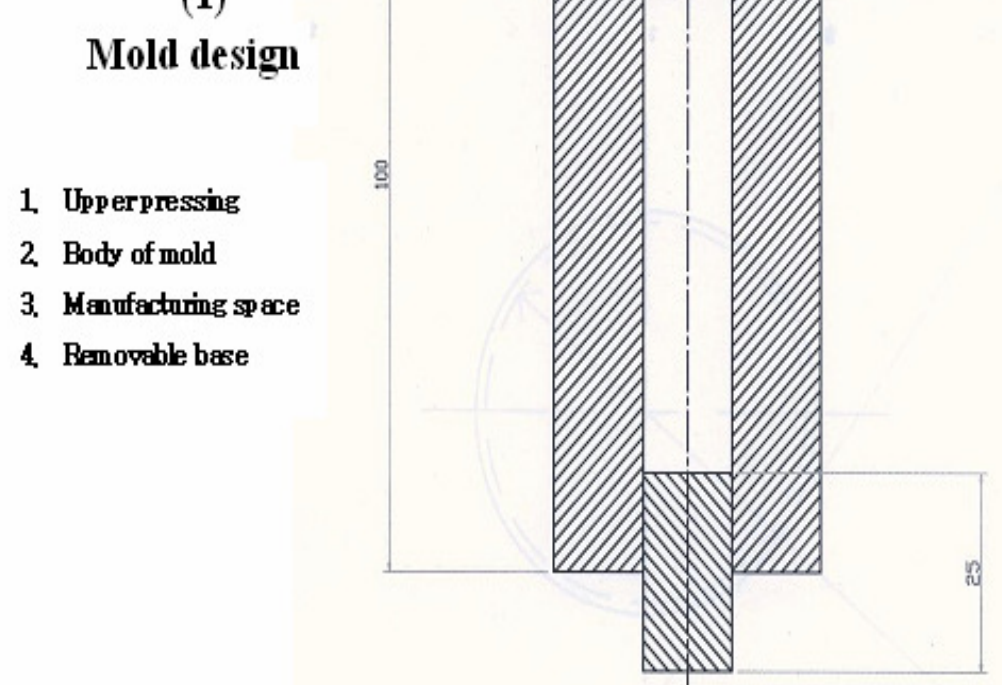

(2) Presssing technique

Fig. 4. The simple design of the molds used in recycling of wastes. 
2. The metals have high thermal conductivity and rapid cooling rates so the thickness of the mold should be sufficient to insure that the inner surface does not lose its temperature before the deformation is completed and prevent early solidification.

3. The body of the mold and the lower pressing are heated from room temperature and treated with special process combined between conventional method of heat treatment and laser surface treatment methods to increase ability to resist wear and friction while increase toughness.

4. Upper pressing may be made from the same treated iron or from special steel

5. The pressure applied on the upper surface of the mold, tolerance between the upper pressing and the mold body allows the gases to escape away during pressing to avoid porous product, which drop the properties and work as crack initiation elements.

\section{Materials Composition and Characteristics}

This research deals with the industrial wastes from a new point of view, the desirable properties in this wastes is studied to benefit from this properties in production of new composite material. Table 1 shows chemical composition of different types of slag and additives, while Table 2 shows physical and thermal characteristics of the additives and reinforcement used in the current work.

Table 1. Chemical composition of different types of slag and additives [22-26].

\begin{tabular}{|c|c|}
\hline Properties & Chemical compositions \\
\hline Adidc slag & $\begin{array}{l}40-45 \% \mathrm{SiO}_{2}, 18-25 \% \mathrm{CaO}, 9-18 \% \mathrm{ALO}_{2}, 4-8 \% \mathrm{FeO}, 2-5 \% \mathrm{MnO} \text {, } \\
1-4 \% \mathrm{MgO}, 0.05-0.1 \% \mathrm{~S})\end{array}$ \\
\hline Baic dag & $\begin{array}{l}25-30 \% \mathrm{SiO}_{2}, 42-50 \% \mathrm{CaO}, 6-8 \% \mathrm{AbO}_{3}, 0.5-1 \% \mathrm{Fe} 0,0.7- \\
1.5 \% \mathrm{MnO}, 12: 15 \% \mathrm{Mg}, 0.9-1.1 \% \mathrm{~S}\end{array}$ \\
\hline Degulphrization & $25-30 \% \mathrm{SiO}_{2}, 42-50 \% \mathrm{CaO}, 6-8 \% \mathrm{Ab}_{2} \mathrm{O}_{3}, 30-20 \% \mathrm{FeO}, 0.7-$ \\
\hline $\mathrm{Sl}_{\mathrm{Ag}}$ & $1.5 \% \mathrm{MnO}, 12: 15 \% \mathrm{Mg} 0,0.9-1.1 \% \mathrm{~S}$ \\
\hline E-type & $52-56 \% \mathrm{SiO}_{2}, 16-25 \% \mathrm{CaO}, 12-16 \% \mathrm{Al}_{2} \mathrm{O}_{3}, 8-13 \% \mathrm{BO}$, \\
\hline flerer flass & $1 \% \mathrm{Na}_{2} \mathrm{O}$ and $1 \% \mathrm{~K}_{2} \mathrm{O}, 0-6 \% \mathrm{MgO}$ \\
\hline
\end{tabular}

\section{Raman Spectroscopy}

The behavior of the material was studied by variation of the modes obtained from FT (IR) Raman spectrum. The results were obtained using Brucker FTIR Raman spectrometer using Nd-YAG laser power of $500 \mathrm{MW}$ as source of excitation. After irradiation the thin film of sample with different lasers, the spectra were obtained in the range 400 to $4000 \mathrm{~cm}^{-1}$. The samples to be measured was fixed to holder and placed in front of the beam [7]. 
Table 2. Properties of industrial wastes and additives [21-22].

\begin{tabular}{|c|c|c|c|c|c|}
\hline Slag & $\begin{array}{l}\text { Moisture } \\
\text { coutent } \\
\text { (Imasis) }\end{array}$ & Density Kgan? & $\begin{array}{l}\text { Coufficient of } \\
\text { themul } \\
\text { condutinity } \\
\text { Whn ."K }\end{array}$ & $\begin{array}{l}\text { Hear } \\
\text { aparity } \\
\text { Fy/Ke . C }\end{array}$ & Hotes \\
\hline Boiler shg & - & 10000 & 0.29 & 0.75 & \\
\hline Lmpslag & - & 2150 & 0.93 & 0.88 & \\
\hline $\begin{array}{l}\text { Hlat } \\
\text { fumuce }\end{array}$ & $20-30 \%$ & $700-400$ & 0.30 .35 & & At $25: 0$ \\
\hline $\begin{array}{l}\text { Fiber plass } \\
\text { Type E }\end{array}$ & & 550 & 0.].4 & $2.1: 25$ & \\
\hline
\end{tabular}

\section{RESULTS \& DISCUSSIONS}

\section{Composite Materials Properties}

In this work, a group of composite materials are prepared by changing the percentage of fibers and slag impeded in the matrix, the corresponding manufacturing conditions is adjusted. The values give an indication about the different compositions which produce a significant improvement in the properties both temperature and applied pressure is changed at each compound. Figure 5 shows ideal packing fractions in practice these values can rarely be approached. In general the increase in fiber glass and additives volume fraction leads to change in structure as shown in Fig. 6 while the improvement in thermal and sound insulation related to the amount of slag impeded in the matrix. Theoretically the increase in strength is continue as the increase in the fiber percentages and additives is increased but in actual practical work the maximum limit of improvement in strength is at $50 \%$ fibers.

\section{Spectroscopic Analysis}

Figure 7 shows the laser Raman spectroscopy of the poly methyl metha acrylate matrix composite reinforced by short fiber glasses with length to diameter ratio equal $\mathrm{L} / \mathrm{D}=1$, this condition produce the maximum improvement in the properties. Then the percentage fibers increases larger than this value, the matrix become unable to imbed more fibers and additive and the strength decreases.

On the other hands when the sound or heat insulation is more preferred in the structure than strength the percentage of additives may reach to $65 \%$, this is considered as the saturation limits of the additives in the matrix, Figure 8 shows the Raman spectrum of the poly methyl metha acrylate matrix composite, the diagram produce a comparison between the two composites have the minimum and maximum 

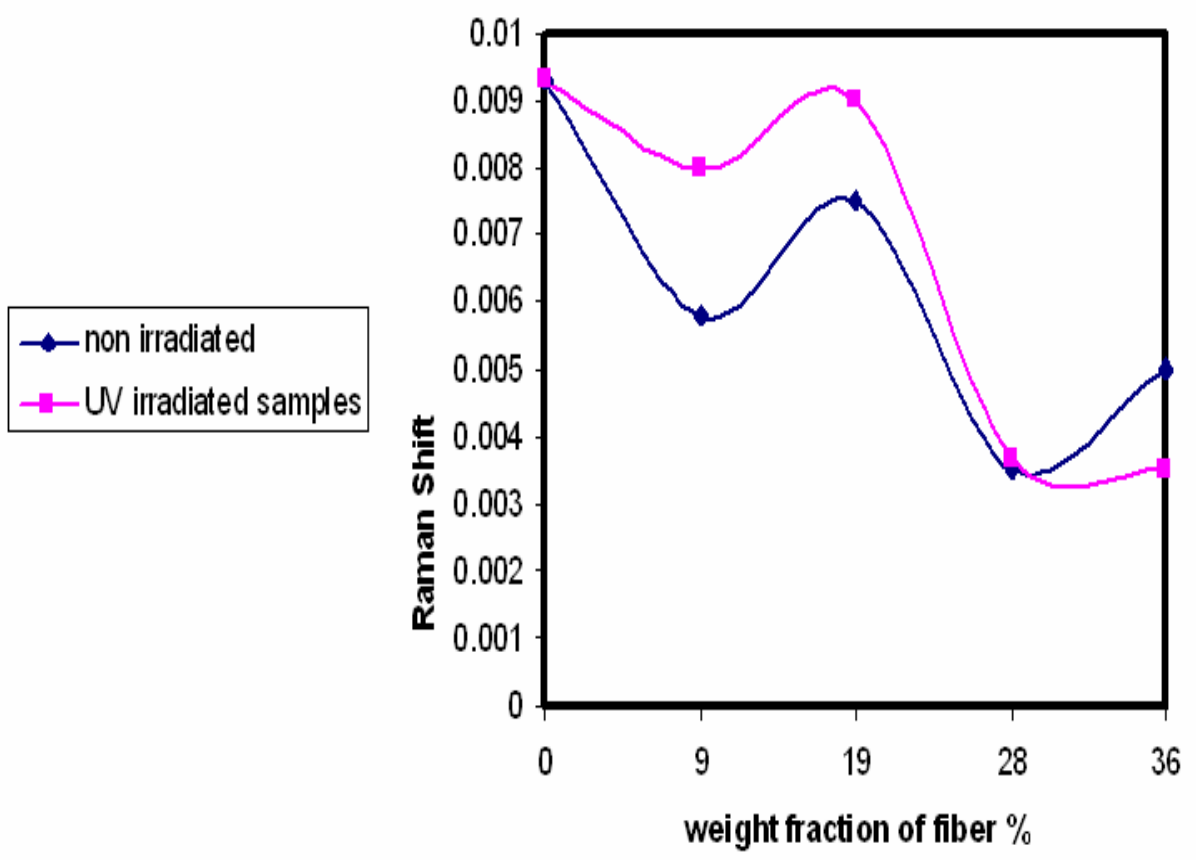

Fig. 6. Structure variation (Raman shift) with variation in additives percentages.

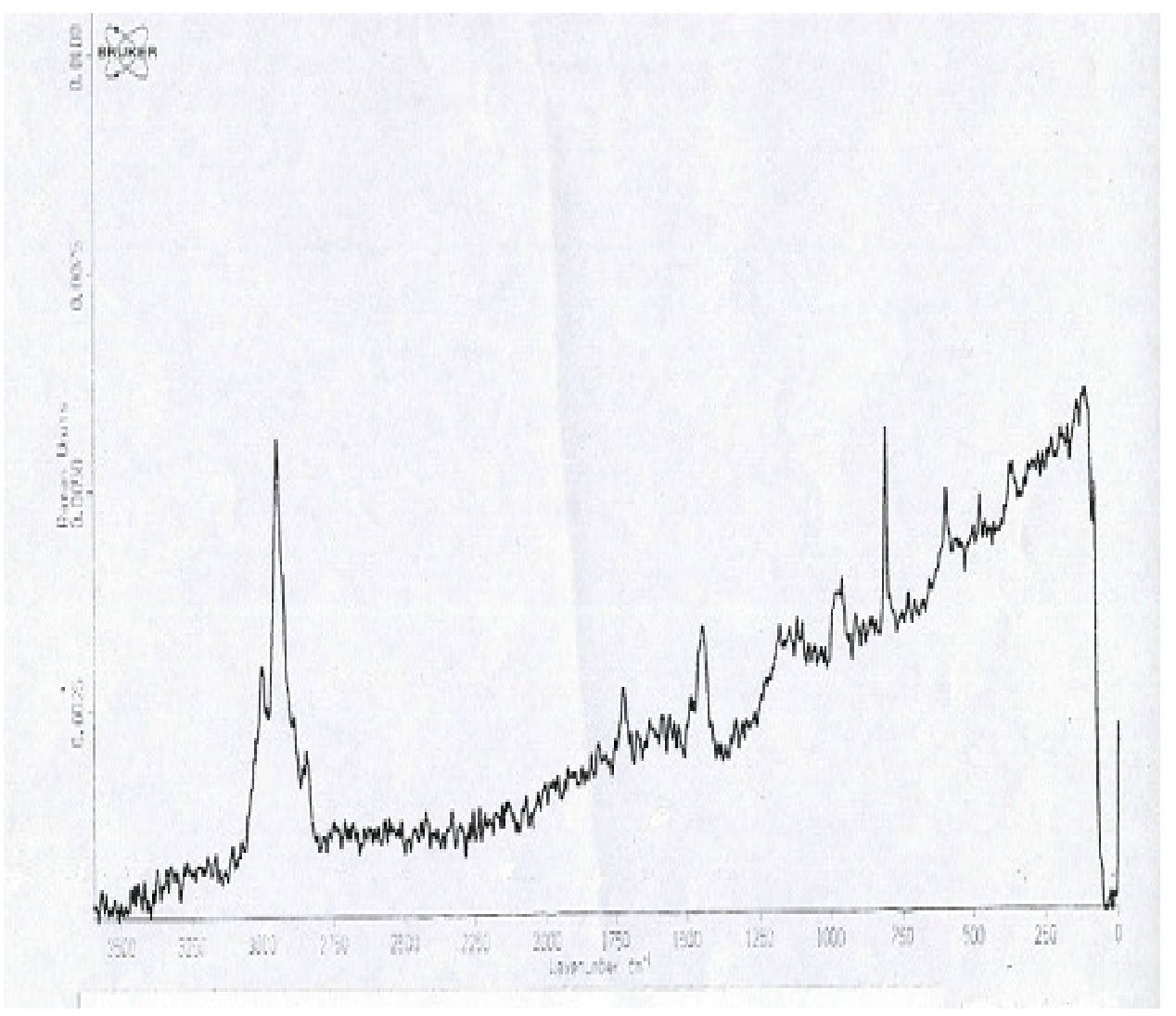

Fig. 7. Raman spectrum for the composite material at maximum improvement in mechanical properties at $50 \%$ Plastics and fiber size $L / d=1$ 
percentages additives (fibers, slag, master patch). At $17 \%$ additives this is the minimum value of additives may produce a significant improvement in the properties of the composite and below this value there almost no change in the properties. When the additive percentages become $65 \%$ this is consider as the maximum available percentage of additives at which the manufacturing process done successfully. The Raman spectrum show a significant difference in amplitude and in the structure at the two cases and this can produce explain for the difference in properties between the two compounds. 0020

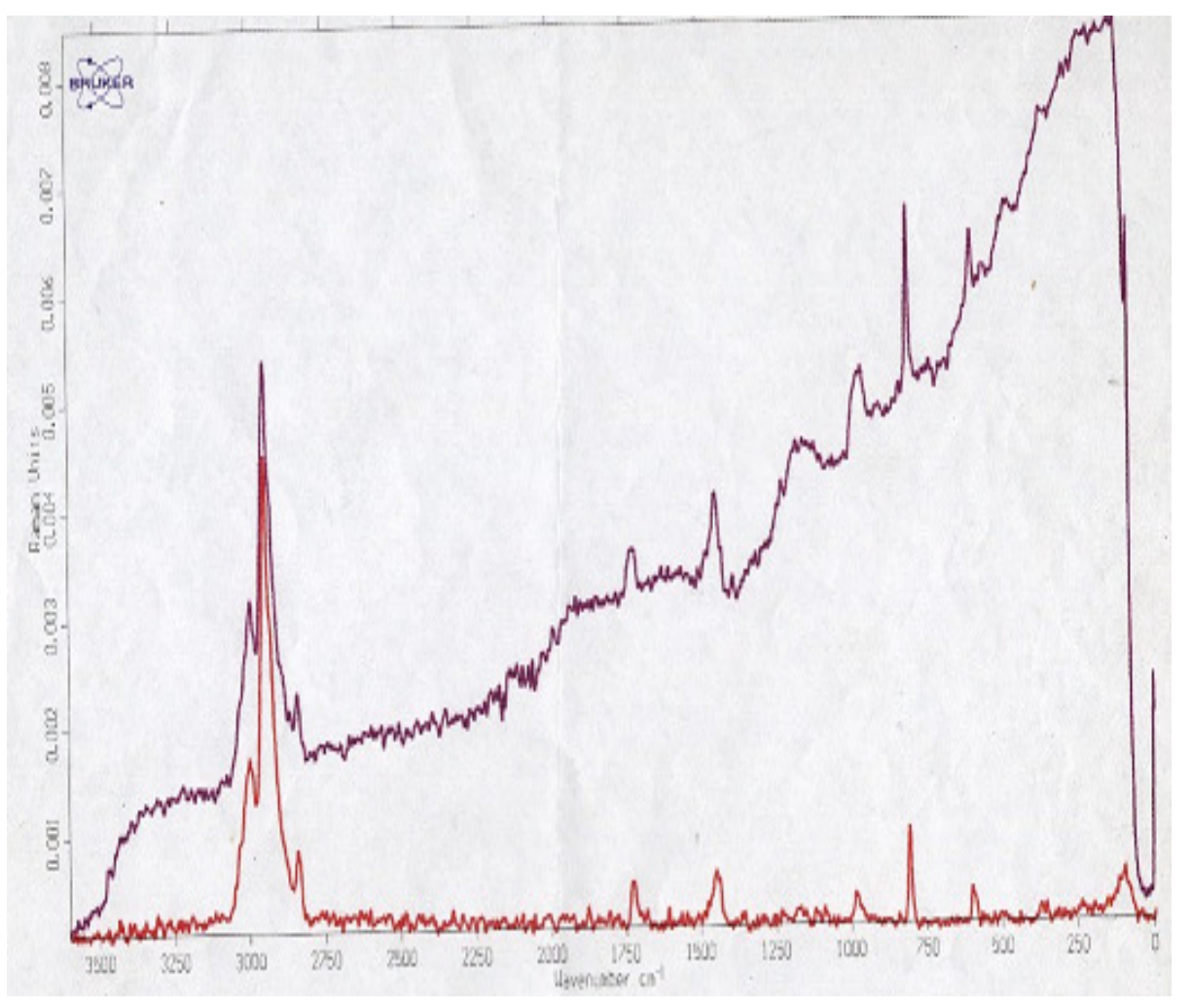

Fig. 8. Raman spectrum for the samples contain minimum percentages of additives $17 \%$ and Maximum percentage of additives $65 \%$.

\section{CONCLUSIONS}

1. The new technique for composite material recycling is simple, abundant and suitable for different types of industrial wastes such as slag and fiber wastes.

2. The properties of the final products depends on the volume fraction of additives (reinforcement) in the composite material structure

3. The new technique is economic because almost $70 \%$ of the contents are wastes, it combined more than one type of wastes

4. The manufacturing conditions depend mainly on the thermoplastic matrix at the same additive percent and volume fraction.

5. The control of additive percentages leads to a material with good insulations characteristics, impact resistance and relatively reasonable strength

6. Slag are used as filling material to improve thermal characteristics of the composite without any pre-preparation or treatment 


\section{REFERENCES}

[1] Medlicott, P., 'Performance of FRP Lined steel Tubing in Production Environment', Fourth International Conference On Composite Materials For Offshore Operations. Houston, TX, October 4 - 6, 2005.

[2] Medlicott, P.,'Static Electricity and the Use of GRP Materials Offshore', Fourth International Conference On Composite Materials For Offshore Operations. Houston, TX, October 4 - 6, 2005.

[3] 'Composite Material Selection \& Implementation in Oil \& gas Applications', Materials Selection for Upstream Oil and Gas" IQPC conference, Aberdeen, 27th January 2004.

[4] 'Static Electricity and the Use of GRP materials Offshore', CMOO-3 Houston 31st October to 2nd November 2000.

[5] 'Composite Materials: Addressing Static Electricity Issues in Offshore Applications' ETCE/OMAE 2000 Conference in New Orleans, February 14 17th, 2000.

[6] 'Progress towards a Qualification Methodology for FRP Lined Tubing and Flowlines in Production Service", Oilfield Engineering with Polymers Conference 26th October 1998.

[7] 'Use of Non-Metallic materials Downhole' Aberdeen 24th April 1998. IBC conference 'Advances in Downhole Technologies'.

[8] 'Qualification Methodology for FRP Lined tubing for Production Service: A Joint Industry PROGRAM' 2nd International Conference on Composite materials for Offshore Operations (CMOO2), Houston, October 28-30 1997.

[9] 'Using Composite Materials to Minimize Weight and Maintenance and Maximize Safety' Euro forum Offshore Platforms '96, London, 18-19th March 1996.

[10] 'How can Composite Materials be Successfully Applied to your Current and Future Offshore Projects? IIR Conference Aberdeen, 15-16th November 1995.

[11] 'Over viewing the Diverse Applications and Advantages of Composites in the Offshore Industry' IIR Conference Aberdeen, 7 - 8th December 1994.

[12] 'GRP and HDPE: Alternative Solutions to Corrosion', UK Corrosion, London 19-21st October 1993.

[13] M.I.Hair, [Infrared spectroscopy in surface chemistry],Marcel Dekker, New York,1967.

[14] Metal handbook,vol. 5, Gambridge university presses, Cambridge ,1970.

[15] Bogomolov V N, Feoktistov N A, Golubev V G, Hutchison J L, Kurdyukov D. A, Pevtsov A B, Sloan J and Sorokin L M 1999 Proc. 7th Int. Symp. 'Nanostructures: Physics and Technology', (St Petersburg, Russia) p 52.

[16] Bogomolov V N, Feoktistov N A, Golubev V G, Hutchison J L, Kurdyukov D A, Pevtsov A B, Schwarz R, Sloan J and Sorokin L M 2000 J. Non-Cryst. Solids 2661081.

[17] Cardona M 1982 Light Scattering in Solids II ed M Cardona and G Guntherodt, Topic in Applied Physics vol 50 (Berlin: Springer) p 117.

[18] Davydov V Yu, Kitaev Yu E, Goncharuk I N, Smirnov A N, Graul J, Semchinova O, Uffmann D, Smirnov M B, Mirgorodsky A P and Evarestov R A 1998 Phys. Rev. B 5812899. 
[19] Filip Van den Abeele, Joris Degrieck, Wim Van Paepegem, Experimental characterization and numerical modeling of impact damage in fibrereinforced composites; Proceedings of the 12th European Conference on Composite Materials, Biarritz, France ( ECCM 2006).

[20] Patricia Verleysen, Joost Van Slycken, Filip Van den Abeele, Joris Degrieck, Advances in High Strain Rate Material Testing; Proceedings of the Ninth International Conference on Structures Under Schock and Impact, Wessex Institute of Technology, New Forest, UK ( SUSI 2006).

[21] Filip Van den Abeele, Joris Degrieck, Wim Van Paepegem, Impact Damage Model for Fibre-Reinforced Composite Materials; Proceedings of the 7th Congress on Theoretical and Applied Mechanics, FPMs-Faculty of Engineering, Mons, Belgium ( NCTAM 2006).

[22] M. Okamoto, Polymer/Clay Nanocomposites, "Encyclopedia of Nanoscience and Nanotechnology" (H. S. Nalwa, Ed.), Vol. 8, p. 1. American Scientific Publishers, Stevenson Ranch, CA, 2004.

[23] Polymer/layered silicate nanocomposites: a review from preparation to processing - REVIEW ARTICLE Progress in Polymer Science, Volume 28, Issue 11, November 2003, Pages 1539-1641 Suprakas Sinha Ray and Masami Okamoto.

[24] Zanetti M, Lomakin S, Camino G. Polymer Layered Silicate Nanocomposites. Macromol Mater Eng 2000; 279: 1-9.

[25] An overview on the degradability of polymer nanocomposites - ARTICLE Polymer Degradation and Stability, Volume 88, Issue 2, May 2005, Pages 234-250 Jitendra K. Pandey, K. Raghunatha Reddy, A. Pratheep Kumar and R.P. Singh. 